\title{
Trace Metal Flux in Water of Buriganga River: A GIS Approach
}

\author{
M. Moniruzzaman*, B. Saha and M. S. Shahariar \\ Laboratories of Soil and Environment, BCSIR Laboratories Dhaka, Dr. Qudrat-I-Khuda Road \\ Dhanmondi, Dhaka-1205.
}

\begin{abstract}
The objective of the study was to explore the seasonal variations in the water of Buriganga River with respect to heavy metals contamination. Water samples were collected six times with an interval of two months starting from June 2010 to April 2011. Collection of samples started at the point of $90^{\circ} 20^{\prime} 12^{\prime \prime} \mathrm{E}$ and $23^{\circ} 46^{\prime} 25^{\prime \prime} \mathrm{N}$, continued towards downstream at an interval of $1 \mathrm{~km}$ upto $26 \mathrm{~km}$ by using GPS and ended at the point of $90^{\circ} 27^{\prime} 36^{\prime \prime} \mathrm{E}$ and $23^{\circ} 37^{\prime} 50^{\prime \prime} \mathrm{N}$. The spatial database of the collected water samples were built with ARCGIS 9.3.1 as the platform of case study of Buriganga River. Six trace metals viz. cadmium (Cd), iron (Fe), zinc ( $\mathrm{Zn})$, chromium $(\mathrm{Cr})$, copper $(\mathrm{Cu})$ and lead $(\mathrm{Pb})$ were analyzed for water from each sampling points to examine the level of contamination whether it exceed or within the permissible limit. The concentrations of trace metals in water samples were determined using atomic absorption spectrophotometer. The concentration range of these trace metals were found 0 to $0.01 \mathrm{mg} / \mathrm{L}$ for $\mathrm{Cd}, 0.46$ to $1.19 \mathrm{mg} / \mathrm{L}$ for Fe, 0 to $0.38 \mathrm{mg} / \mathrm{L} \mathrm{for} \mathrm{Zn}, 0$ to $0.074 \mathrm{mg} / \mathrm{L}$ for Cu, 0 to $0.098 \mathrm{mg} / \mathrm{L}$ for $\mathrm{Cr}$ and 0 to $0.074 \mathrm{mg} / \mathrm{L}$ for $\mathrm{Pb}$. The study suggested that, concentration of $\mathrm{Fe}, \mathrm{Cr}$ and $\mathrm{Cd}$ in river water were increased during dry season and in some points near Hazaribagh, Zinzira and Sadarghat it crossed the maximum permissible limit for drinking water purposes and irrigation water supply.
\end{abstract}

Key words : Buriganga River, Trace metals, GIS Technology

\section{Introduction}

Bangladesh is a riverine country. A large number of rivers flowing through Bangladesh originated out of the country. These rivers carry heavy loads of sediments and other debris including domestic wastes, agrochemicals and industrial wastes from local and far places thus making the water body saturated with organic and inorganic pollutants which affect the environment.

The environment, economic growth and developments of Bangladesh are highly influenced by regional and seasonal availability of river water and the quality of surface and groundwater. In terms of quality, the surface water of the country is unprotected from untreated industrial effluents and municipal wastewater, runoff pollution from chemical fertilizers and pesticides. Water quality also depends on effluent types and discharge quantity from different type of industries and seasonal water flow and dilution capability by the river system (DHV, 1998).

The occurrence of metal contaminants especially the trace metals in excess from various sources of natural loads has become a problem of increasing concern. This situation has arisen as a result of rapid growth of population, increased urbanization, expansion of industrial activities, exploration and exploitation of natural resources and agricultural practices.

Rapid urbanization and industrial development during last decade have provoked some serious concerns for the environment. Heavy metal contamination in river is one of the major quality issues in many fast growing cities, because maintenance of water quality and sanitation infrastructure did not increase along with population and urbanization growth especially for the developing countries (Sundaray et al., 2006; Karbassi et al., 2008; Akoto et al., 2008; Ahmad et al., 2010).

At present, Dhaka city alone generates about 3500 to 4000 MT of solid wastes per day. The amount increases with the increase of population every year. The domestic, commercial, street sweeping, degradable and non-degradable wastes including discarded food, grass, plants, paper, cardboard, textiles, plastics, polythene materials, glass, metals, and construction debris are discharged into the river (Ahmad et al. 2010). The Buriganga River is apprehended to be one of the polluted parts of the river system of Bangladesh. The present 
study aimed to visualize the water quality status of the Buriganga River with respect to its heavy metal concentrations in various seasons with spatial variations.

\section{Materials and Methods}

The Buriganga River encompasses the south-western periphery of Dhaka City. It originates from Dhaleswari from north of Dhaka and meets it again south of Dhaka City. The Buriganga River has been selected as a case study for this research. Water sampling started from the point of $90^{\circ} 20^{\prime} 12^{\prime \prime} \mathrm{E}$ and $23^{\circ} 46^{\prime} 25^{\prime \prime} \mathrm{N}$, continued downward at an interval of $1 \mathrm{~km}$ for $26 \mathrm{~km}$ and ended at the point of $90^{\circ} 27^{\prime} 36^{\prime \prime} \mathrm{E}$ and $23^{\circ} 37^{\prime} 50^{\prime \prime} \mathrm{N}$. Total number of samples collected during each sampling was 27. Location of the sampling points was confirmed by GPS.

Water samples were collected at each point with water sampler (Model: UWITEC, A-3510, USA) in the midstream at a

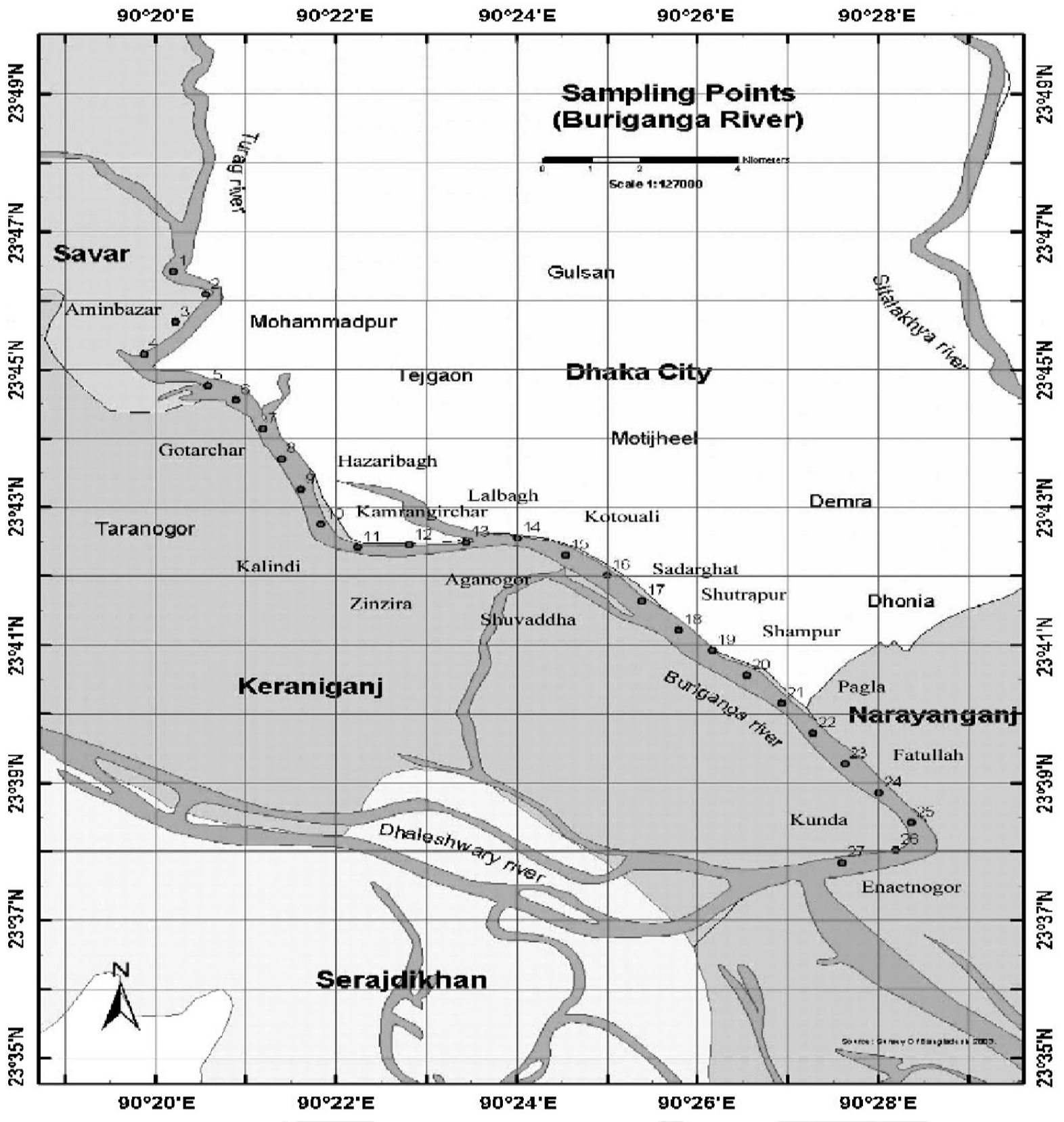

Fig. 1: Sampling points in Buriganga river. 
depth of 1 to 2 meters to avoid the interference of floating substances. Sample collection was conducted six times at an interval of two months from June 2010 to April 2011. Highdensity 1-liter PVC bottles were used for water sample collection. Each bottle was cleaned thoroughly by rinsing with dilute $\mathrm{HNO}_{3}$ followed by washing with distilled water (De, 1989). Water samples were collected from all the sampling points of the Buriganga River. The collected samples were filtered and preserved with Conc. $\mathrm{HNO}_{3}$ (APHA, 1998). Nitric acid addition to obtain the required $\mathrm{pH}(\mathrm{pH}<2)$ is most frequently recommended for the analysis of trace metals and also for preservation of water samples (APHA, 1998 and USEPA, 1979). Wilson (1974) found that acidification decreased the precipitation of $\mathrm{Fe}, \mathrm{Cu}, \mathrm{Ni}, \mathrm{Cd}$, and $\mathrm{Zn}$ from water samples. Trace metals $\mathrm{Cd}, \mathrm{Fe}, \mathrm{Cu}, \mathrm{Cr}, \mathrm{Pb}$ and $\mathrm{Zn}$ in water of Buriganga River were analyzed by using Atomic Absorption Spectroscopy (Model: Shimadzu- AA7000).

\section{Results and Discussion}

Six trace metals viz. cadmium, iron, zinc, chromium, copper and lead were analyzed for water from each sampling points to obtain the level of contamination.

The results revealed that cadmium concentration of water collected at different points and at different times of a year ranged from BDL to $0.01 \mathrm{mg} / \mathrm{L}$. Among sampling points, it was observed that, in February and April water from sampling points 8 to 17 (Fig. 1) near Hazaribagh, Kamrangirchar, Zinzira and Sadarghat showed high Cd concentration around $0.008 \mathrm{mg} / \mathrm{L}$. In April, water from sampling point 13 and 14 near Lalbagh-Sadarghat showed the maximum Cd concentration $0.011 \mathrm{mg} / \mathrm{L}$ (Fig 1), which was higher than the permissible limit according to DoE (Table I). The major source of $\mathrm{Cd}$ in water is the coal combustion, metal industry and waste incineration into the river (Brian and Bishop, 2009). Again, sampling point 1 to 6 and 22 to 27 in all seasons showed low $\mathrm{Cd}$ concentration due to limited industrial activities.

Average Cd concentration of water was comparatively high from December to April and the highest average Cd concentration of water was found during the month of February $(0.0041 \mathrm{mg} / \mathrm{L})$ (Fig. 3). On the other hand, the average $\mathrm{Cd}$ concentration of water was comparatively low during wet season from August to October (around $0.001 \mathrm{mg} / \mathrm{L}$ ) due to dilution effect.

As per FAO, USEPA and DoE recommendation, average $\mathrm{Cd}$ concentration in the Buriganga river water was within safe limit (Table I). But among sampling point variation $\mathrm{Cd}$ concentrations in dry season exceed the permissible limit as drinking water purpose according to DoE standard.

Iron concentration of water collected at different points and at different times of a year ranged from 0.35 to $1.72 \mathrm{mg} / \mathrm{L}$. Sampling points variation revealed that, in February and April water from sampling points 11 to 18 near Hazaribagh, Kamrangirchar, Zinzira and Sadarghat areas showed high Fe conc. around $1.5 \mathrm{mg} / \mathrm{L}$ (Fig. 1). High Fe concentration in water occur due to discharge of effluent from metal alloys industries (Brian and Bishop, 2009). Again water from sampling points

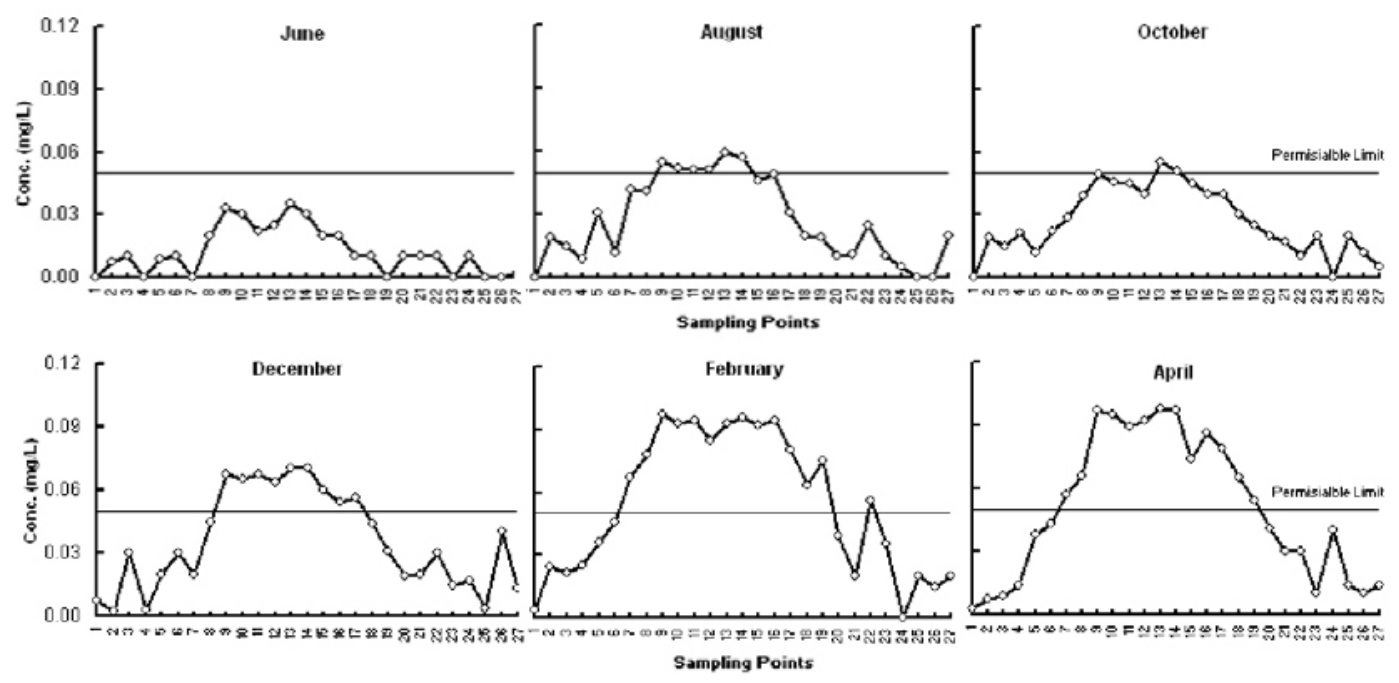

Fig. 2: Cadmium (Cd) conc. (mg/1) in Buriganga River water at different points and at different months of year. 
22 to 24 near Fotullah port of Narayanganj also showed high Fe conc. (1.0 to $1.5 \mathrm{mg} / \mathrm{L})$ due to presence of some dockyards beside river (Fig. 1).

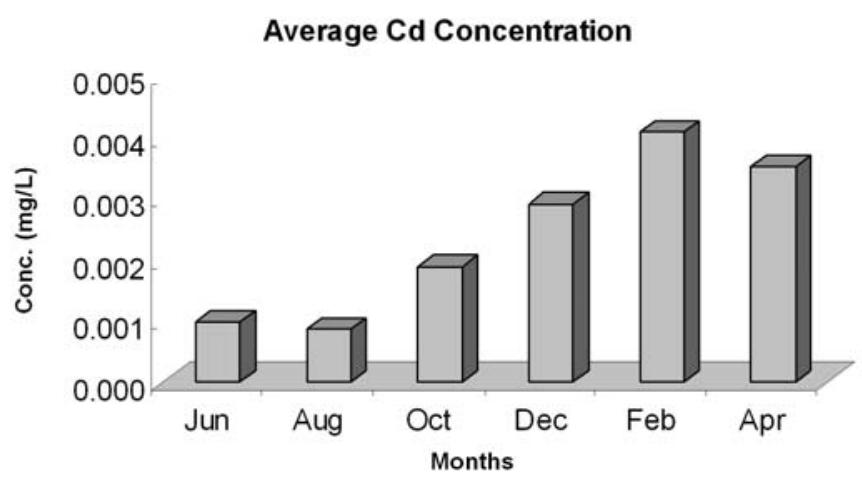

Fig. 3: Average Cd Concentration in Buriganga river water as drinking water purpose according to USEPA drinking water standard (Table I).

Zinc concentration of water of Buriganga river collected at different points and at different times of year ranged from 0 to $0.38 \mathrm{mg} / \mathrm{L}$. Among sampling points variation it was observed that, in February and April water from sampling points 10 to 18 near Sadarghat, Hazaribagh and Kamrangirchar areas showed high $\mathrm{Zn}$ concentration around $0.3 \mathrm{mg} / \mathrm{L}$ (Fig. 1). High $\mathrm{Zn}$ concent in river water may be attributed to domestic swage and runoff from extensive farmed areas (Wu et al., 2008). In contrast water from sampling points 1 to 7 and 22 to 24 showed low $\mathrm{Zn}$ concentration around $0.05 \mathrm{mg} / \mathrm{L}$ due to limited industrial activities (Fig. 1).
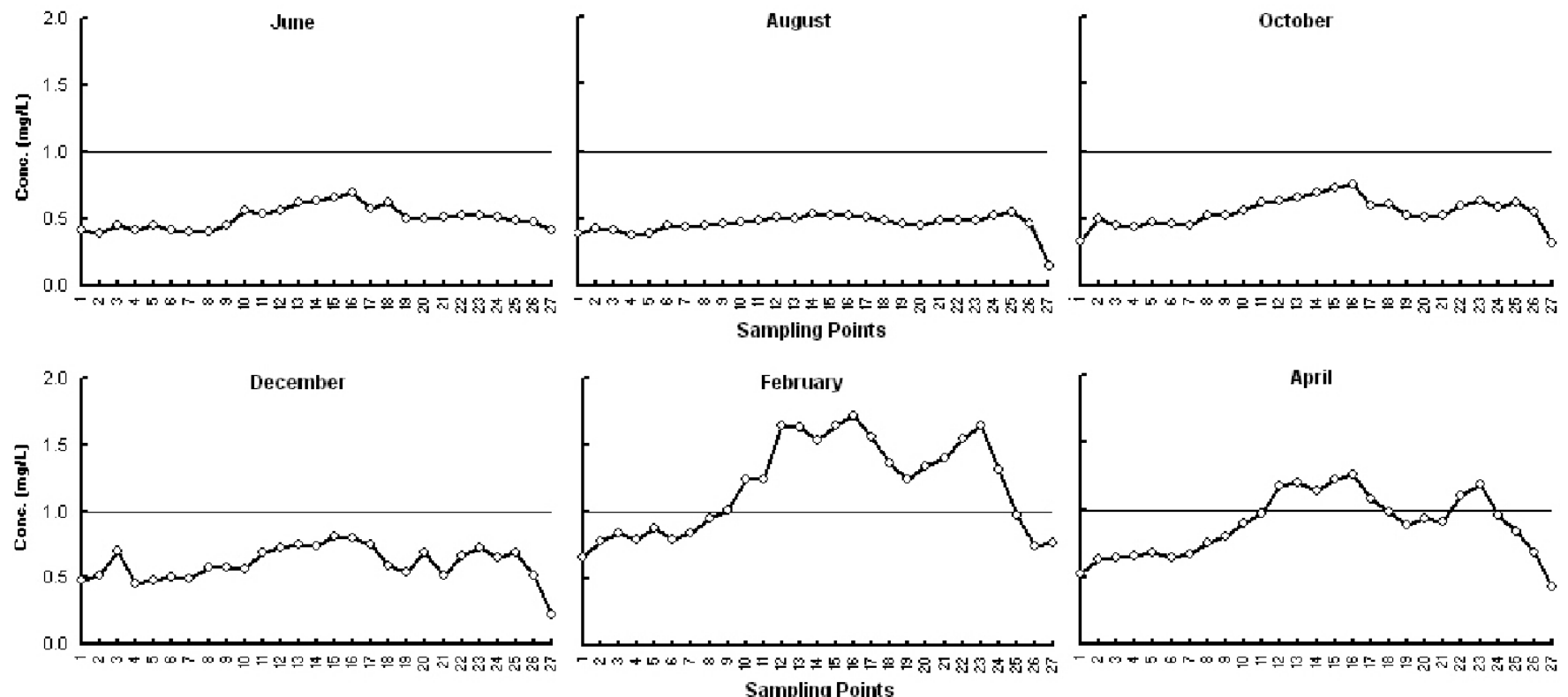

Fig. 4: Iron conc. $(\mathrm{mg} / \mathrm{L})$ of Buriganga river water at different points and at different months of year.

Average Fe concentration of water collected at different times of a year ranged from 0.46 to $1.19 \mathrm{mg} / \mathrm{L}$. The Fe concentration of water was relatively high from December to April and the highest average Fe concentration $1.19 \mathrm{mg} / \mathrm{L}$ of water was found during the month of February (Fig. 5).

On the other hand, Fe concentration of water was relatively low during wet season from June to October and lowest average $\mathrm{Fe}$ concentration in river water was observed in August. According to FAO recommended level iron concentration in river water was within safe limit as irrigation water supply. But average iron concentration exceeds the safe limit
Average $\mathrm{Zn}$ concentration of water ranged from 0.064 to $0.161 \mathrm{mg} / \mathrm{L}$ (Table I). The Zn concentration of water was relatively high in dry season from December to April and relatively low during wet season from June to October. The highest average $\mathrm{Zn}$ concentration of water found in February (0.161 mg/L) (Fig. 7) followed by April.

According to FAO, USEPA and DoE recommended level Zn concentration in Buriganga river water was within safe limit as irrigation water supply and drinking water purposes throughout the year (Table I). The low values of $\mathrm{Zn}$ indicate there is no significant source of pollution in respect of $\mathrm{Zn}$. 


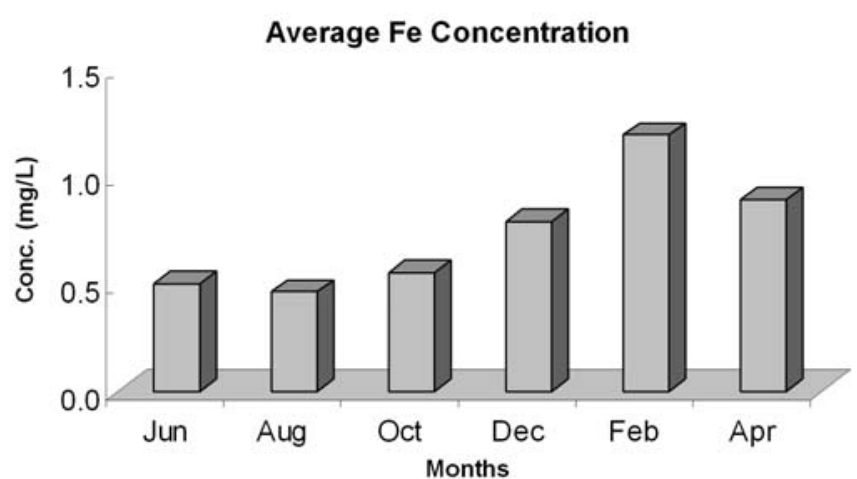

Fig. 5: Average Fe Concentration in Buriganga river water
Average $\mathrm{Cu}$ concentration of water was comparatively high from February to April with average value in the range of 0.02 to $0.026 \mathrm{mg} / \mathrm{L}$ and the highest average copper concentration of water found in February $(0.026 \mathrm{mg} / \mathrm{L})$. On the other hand, copper concentration of water was comparatively low from August to October $(0.006$ to $0.007 \mathrm{mg} / \mathrm{L})$ due to dilution effect. The lowest average copper concentration found in August (0.006 mg/L) (Fig. 9).

According to FAO and USEPA recommended level, in February and April average $\mathrm{Cu}$ concentration in river water cross the permissible limit as drinking water purpose and irrigation water supply (Table I).
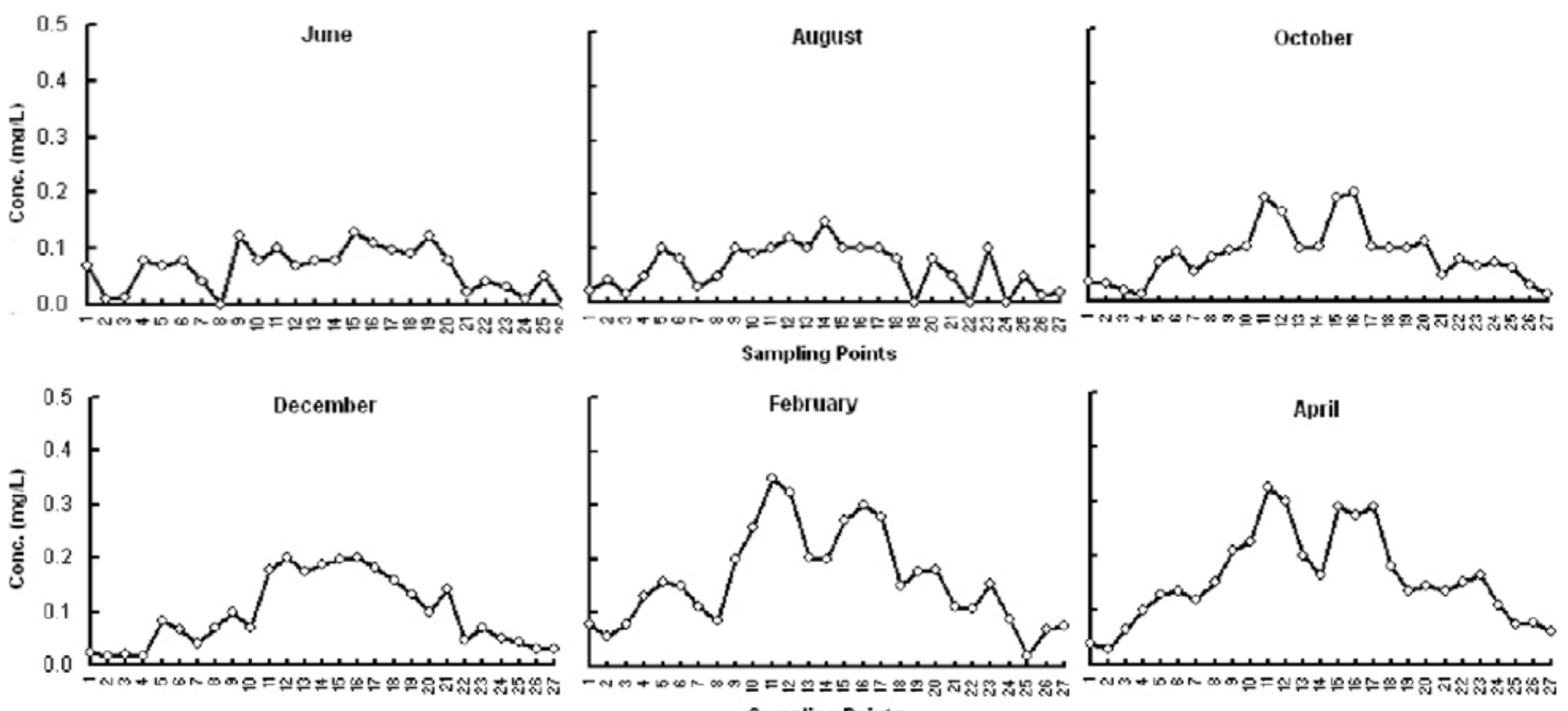

Fig. 6: Zinc conc. (mg/L) of Buriganga river water at different points and at different months of year.

In the study area copper concentration of water collected at different points and at different times of year ranged from 0 to $0.074 \mathrm{mg} / \mathrm{L}$ (Fig. 8). Among sampling points variation it observed that, in February and April water from sampling points 9 to 12 (Hazaribagh, Kamrangirchar and Zinzira areas) and sampling points 15 to 19 (Sadarghat and Sutrapur areas) showed comparatively high $\mathrm{Cu}$ concentration around $0.05 \mathrm{mg} / \mathrm{L}$ and in February water from sampling point 17 near Sadarghat showed the maximum $\mathrm{Cu}$ concentration $(0.074 \mathrm{mg} / \mathrm{L})$ (Fig. 8). High Cu content may be attributed to domestic sewage and run-off from industrial and urban garbage (Wu et al., 2008). Again, water from sampling point 1 to 8 and 22 to 27 in all seasons showed low Copper concentration due to limited industrial activities (Fig. 1).

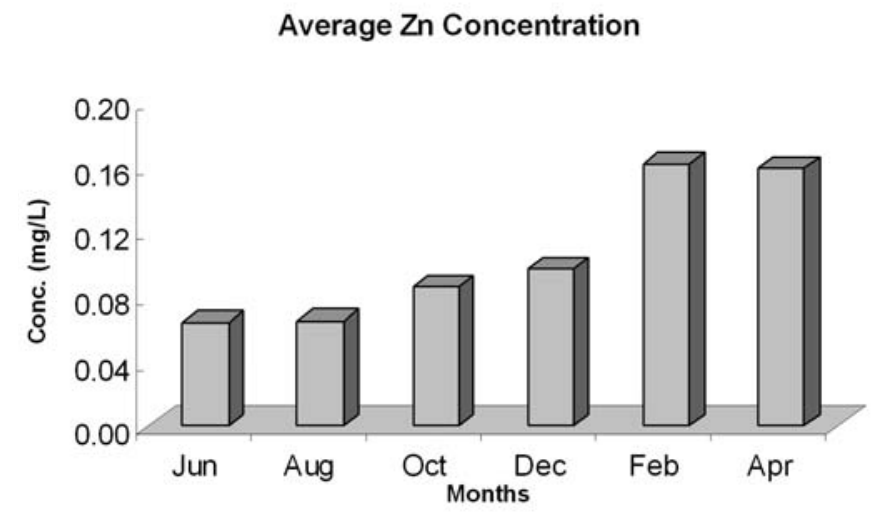

Fig. 7: Average $\mathrm{Zn}$ Concentration in Buriganga river water 

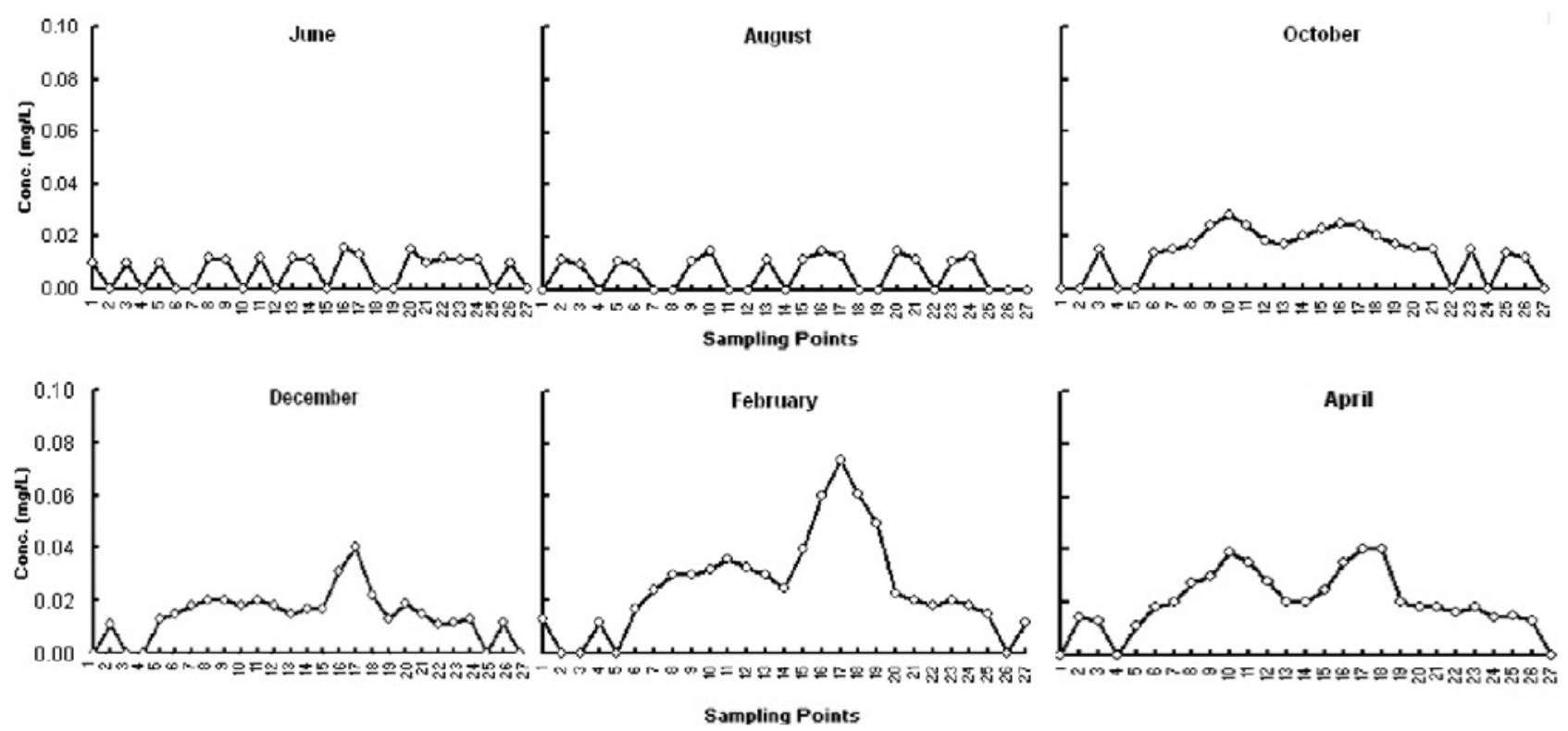

Fig. 8: Copper conc. (mg/L) of Buriganga river water at different points and at different months of year.

According to FAO and USEPA recommended level, in February and April average $\mathrm{Cu}$ concentration in river water cross the permissible limit as drinking water purpose and irrigation water supply (Table I). the year. Average $\mathrm{Cr}$ concentration in river water range from 0.012 to $0.054 \mathrm{mg} / \mathrm{L}$. Maximum average $\mathrm{Cr}$ concentration of water found in the month of February $(0.054 \mathrm{mg} / \mathrm{L})$ (Fig. 11). This may be due to various urban and industrial activi

Table I: Average trace metals concentration $(\mathrm{mg} / \mathrm{L})$ in Buriganga river water with recommendation values.

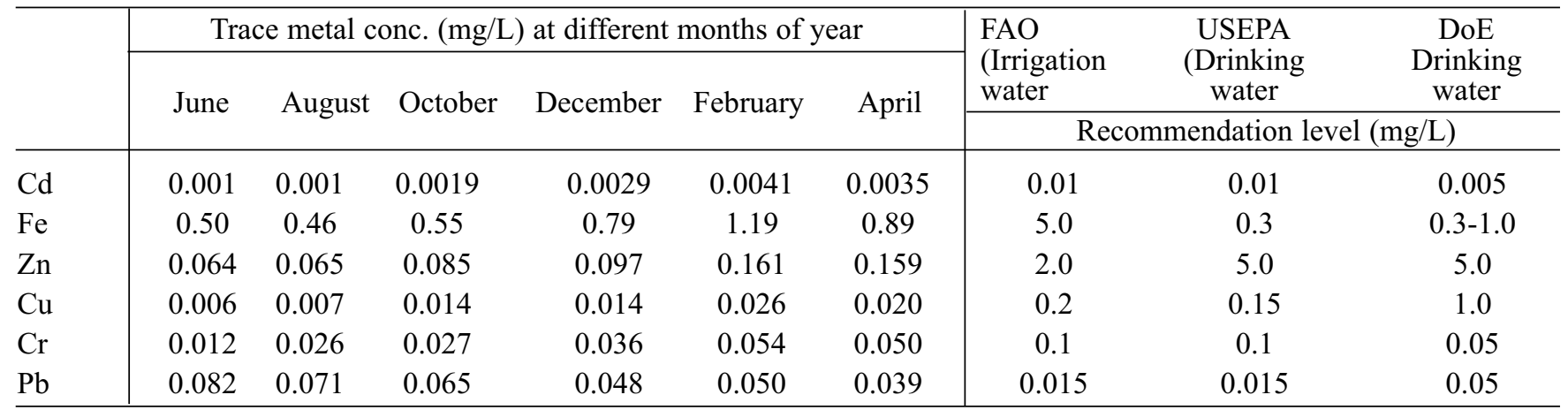

In February and April water from sampling points 15 to 17 near Kotouali and Sadarghat also showed high Cr concentration (Around 0.08 to $0.09 \mathrm{mg} / \mathrm{L}$ ). Again, water from sampling point 1 to 7 and 20 to 27 in all season showed low Chromium concentration due to limited industrial activities (Fig. 10).

$\mathrm{Cr}$ concentration of Buriganga river water was comparatively high from February to April and the concentration exceeds permissible limit in some points. Beside this chromium concentrations of river water were within safe limit throughout
Average Cu Concentration

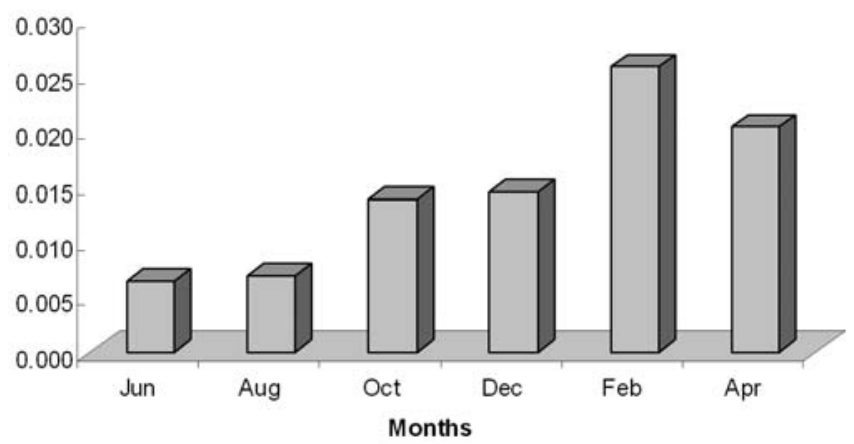

Fig. 9: Average $\mathrm{Cu}$ Concentration in Buriganga river water 
ties around river with low volume of water during dry period. On the other hand, average chromium concentration of water was low during wet season from June to October (around 0.012 to $0.027 \mathrm{mg} / \mathrm{L}$ ). This may be due to dilution effect. The lowest average Chromium concentration in water found during the month of June (0.012 mg/L) (Fig. 11).

According to FAO, USEPA and DoE recommended level $\mathrm{Cr}$ concentration in Buriganga river water was within safe limit during wet season. But $\mathrm{Cr}$ concentration in river water cross the safe limit as drinking water purpose according to DoE standard during wet season (Table I). the range of 0.062 to $0.079 \mathrm{mg} / \mathrm{L}$ and the highest average lead concentration of water observed during the month of June $(0.082 \mathrm{mg} / \mathrm{L})$ (Fig. 13). High concentration of lead excrete form smock of vehicles and finally washout with rain water into the river during wet season. On the other hand, the average lead concentration of water was comparatively low during dry season from December to April (average value 0.034 to $0.05 \mathrm{mg} / \mathrm{L}$ ) due to low rainfall (Fig. 13).

According to FAO, USEPA and DoE recommended level average $\mathrm{Pb}$ concentration in Buriganga river water crossed the permissible limit as irrigation water supply and drinking water purpose through whole year (Table I).
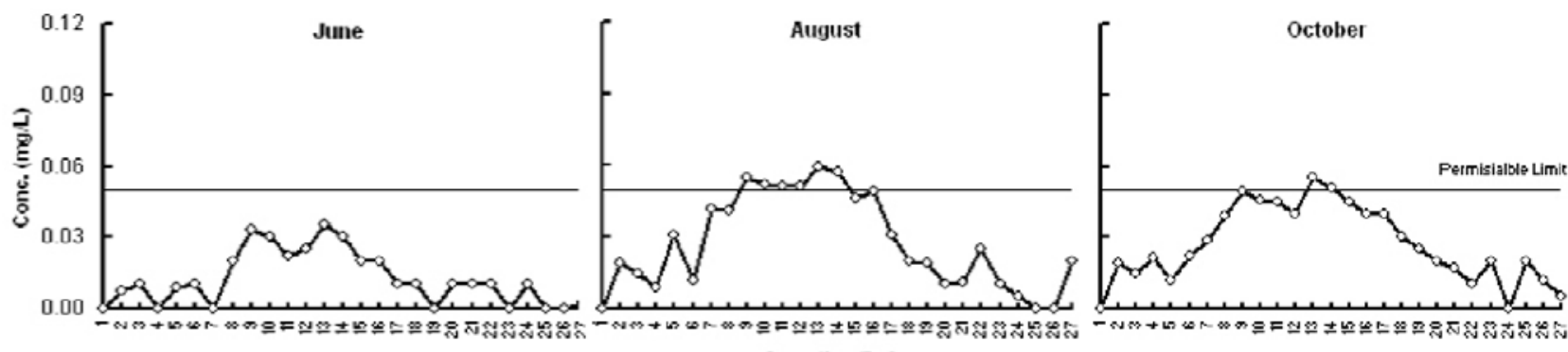

Sampling Points

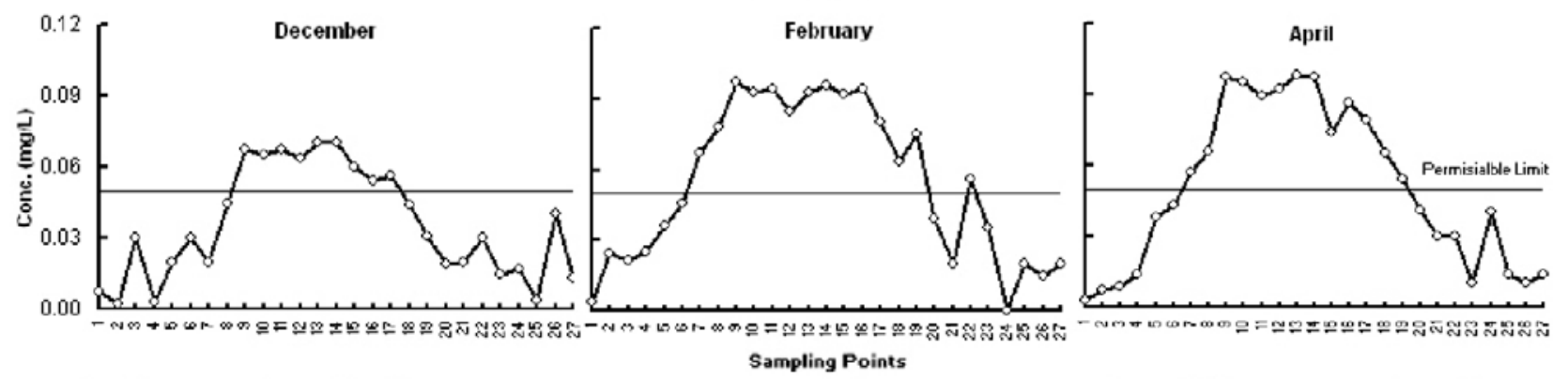

Fig. 10: Cr conc. (mg/L) of Buriganga river water at different points and at different months of year.

In the study area lead concentration of water collected at different points and at different times of year ranged from 0 to $0.13 \mathrm{mg} / \mathrm{L}$. Among sampling points variation it observed that, from June to October water from sampling points 8 to 22 near Hazaribagh, Zinzira, Lalbagh, Sadarghat and Shutrapur showed high $\mathrm{Pb}$ concentration around $0.1 \mathrm{mg} / \mathrm{L}$ (Fig. 12). In June water from sampling point 9 near Hazaribagh showed the highest $\mathrm{Pb}$ concentration in water $(0.13 \mathrm{mg} / \mathrm{L})$ (Fig. 12) which was much higher than the permissible limit (Table I). This may be due to high urban activities. In August water form sampling point 17 near Sadarghat and in October water from sampling point 19 near Shutrapur also showed very high $\mathrm{Pb}$ concentration (Around $0.1 \mathrm{mg} / \mathrm{L}$ ) due to same reason (Fig. 12).

The $\mathrm{Pb}$ concentration of water was comparatively high during wet season from June to October with average value in

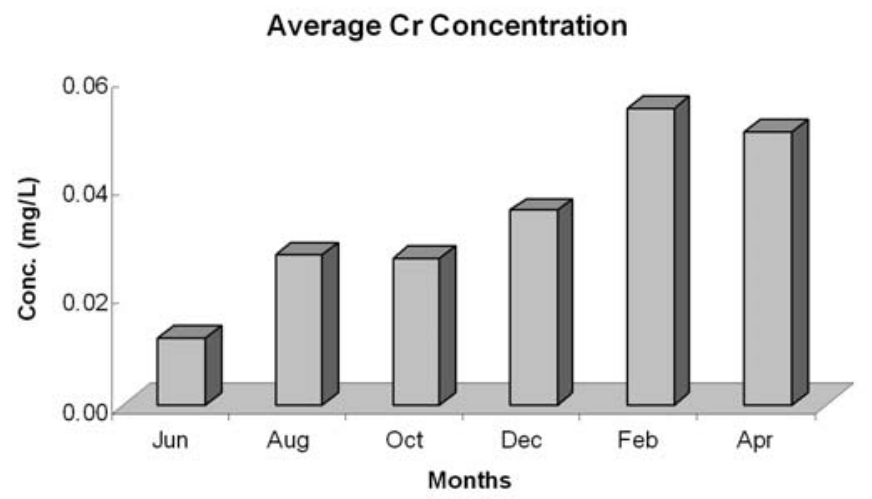

Fig. 11: Average $\mathrm{Cr}$ Concentration in Buriganga river water

Most of the heavy metals showed slightly high concentrations during the dry period than that of the wet season. These kinds of pattern indicate the accumulation of the metal dur- 

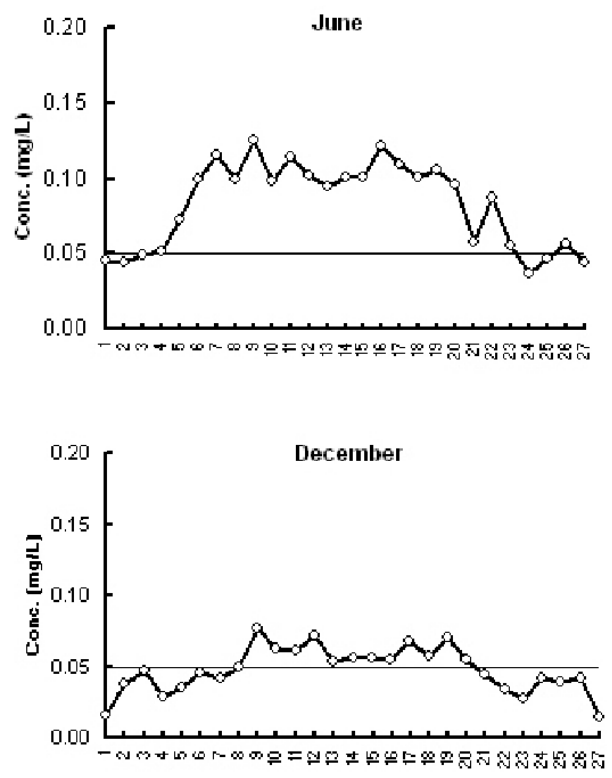

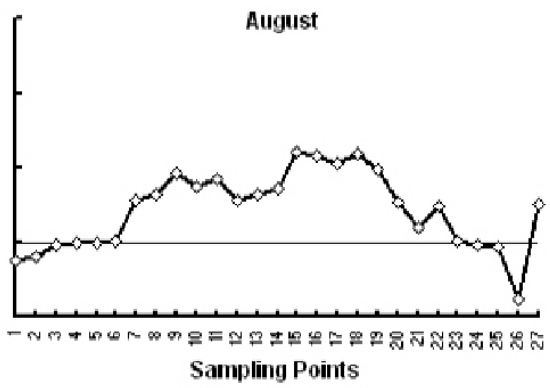

Sampling Points

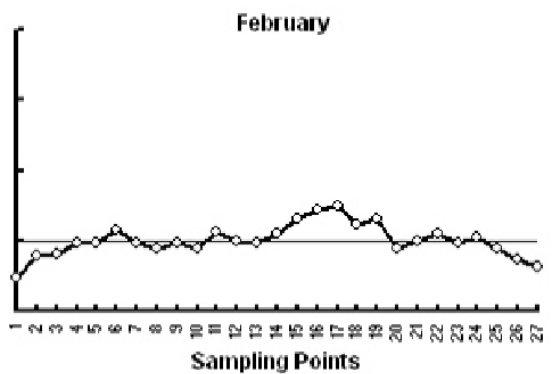

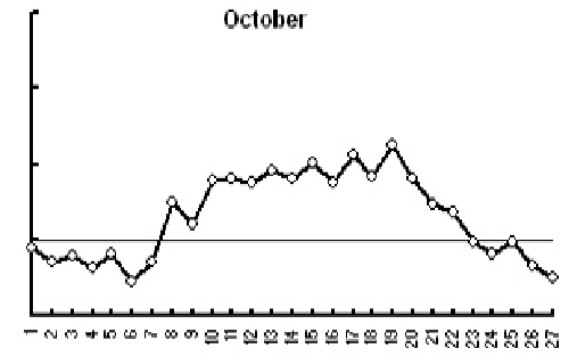

April

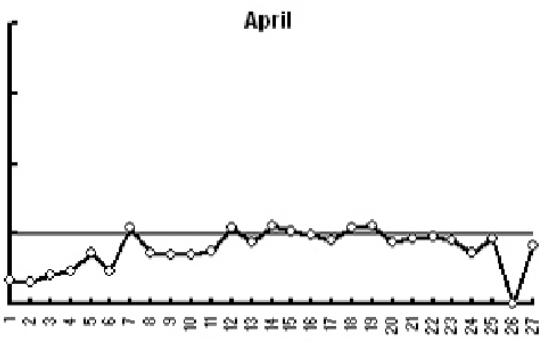

Fig. 12: $\mathrm{Pb}$ conc. (mg/L) of Buriganga river water at different points and at different months of year.

ing low flow condition of river (Abdel-Satar, 2001). The previous studies has been ensure that the atmospheric precipitation is very much responsible for metal contamination in surface water (Wong et al., 2003; Wu et al., 2008; Pandey et al., 2009).

Metal concentrations were significantly different between sampling stations. It was also observed that for all metals studied; there was a trend of increasing concentrations from midstream stations. This may be due to presence of various unplanned recycling industries on those areas.

Trace elements occur in almost all water supplies but at very low concentrations, usually less than a few $\mathrm{mg} / \mathrm{L}$. Not all trace elements are toxic and in small quantities many are essential for plant growth. However, excessive quantities will cause undesirable accumulations in plant tissue and growth reductions and when one is exposed to high concentrations, it can cause health problems.

Trace metal contaminations are important due to their potential toxicity for the environment and human beings (Gueu et al., 2007; Lee et al., 2007; Adams et al., 2008; Vinodhini and Narayanan, 2008). Some of the metals like $\mathrm{Cu}, \mathrm{Fe}, \mathrm{Mn}$, and $\mathrm{Zn}$ are essential as micronutrients for the life processes in animals and plants while many other metals such as $\mathrm{Cd}, \mathrm{Cr}$, $\mathrm{Pb}$ have no known physiological activities (Kar et al., 2008; Suthar and Singh, 2008; Aktar et al., 2010). Metals are nondegradable and can accumulate in the human body system,

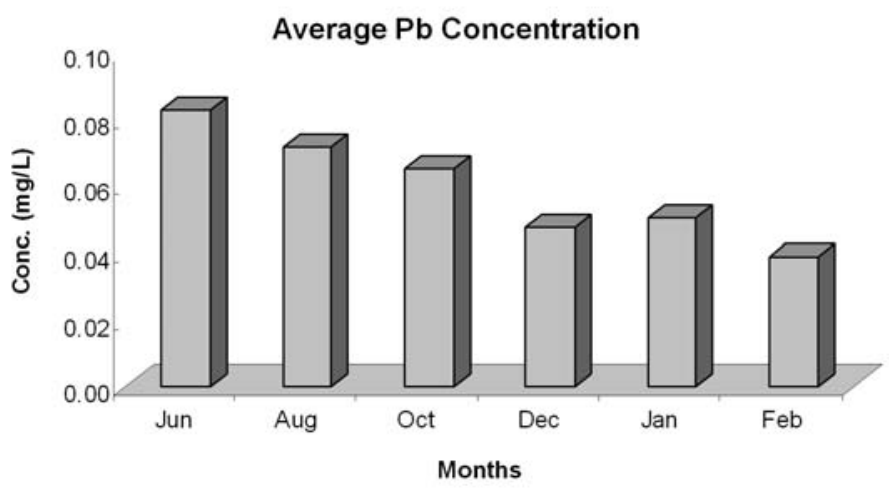

Fig. 13: Average $\mathrm{Pb}$ Concentration in Buriganga river water

causing damage to nervous system and internal organs (Lee et al., 2007; Lohani et al., 2008). However, the rivers play a major role in assimilation or transporting municipal and industrial wastewater and runoff from agricultural and mining land (Singh et al., 2004).

\section{Conclusion}

The present study disclosed that most of the water samples collected from Buriganga River was polluted by heavy metal contamination and shows a trend in seasonal variation. From laboratory analysis significant trace metal concentration in the water of Buriganga River were found during dry seasons which was attributed due to the high density of various industries along with the river course. Heavy metals concentration in Buriganga River was found comparatively low in 
wet season. Trace metal concentrations from industrial effluents has been diluted rapidly with respect to a very small distance due to the presence of adequate flow rate in the river.

\section{References}

Abdel Satar A. M. (2001). Environmental studies on the impact of the drains effluent upon the southern sector of Lake Manzalah. Egypt. J. Aquat. Biol. Fish. 5:17-30.

Adams R. H., Guzmán O. F. J. and Zavala C. J. (2008). Water repellency in oil contaminated sandy and clayey soils. Int. J. Environ. Sci. Tech. 5 (4): 445-454.

Ahmad M. K., Islam S., Rahman S., Haque M. R. and Islam M. M. (2010). Heavy Metals in Water, Sediment and Some Fishes of Buriganga River, Bangladesh Int. J. Environ. Res., 4(2): 321-332.

Akoto O., Bruce T. N. and Darko G. (2008). Heavy metals pollution profiles in streams serving the Owabi reservoir. African J. Environ. Sci. Tech. 2 (11): 354-359.

Aktar M. W., Paramasivam M., Ganguly M., Purkait S. and Sengupta D. (2010). Assessment and occurrence of various heavy metals in surface water of Ganga river around Kolkata: a study for toxicity and ecological impact. Environ. Monitor. Assess. 160 (1-4): 207-213.

APHA (American Public Health Association). (1998). Standard methods for examination of water and waste water (20th. Ed.). Washington DC. 1134 p.

Brian S. C. and Bishop M. (2009). Seasonal and spatial variation of metal loads from natural flows in the upper Tenmile Creek watershed, Montana. Mine Water Environ., 28 (3): 166-181.

De A. K. (1989). Environmental Chemistry. Wiley Eastern Ltd., New Delhi, India. 42-43.

DHV (1998). Meghna Estuary Study, Draft Master Plan, Volume 1, Main Report for BWDB, Dhaka, Bangladesh.

Gueu S., Yao B., Adouby K. and Ado G. (2007). Kinetics and thermodynamics study of lead adsorption on to activat- ed carbons from coconut and seed hull of the palm tree. Int. J. Environ. Sci. Tech. 4 (1): 11-17.

Kar D., Sur P., Mandal S. K., Saha T. and Kole R. K. (2008). Assessment of heavy metal pollution in surface water. Int. J. Environ. Sci. Tech. 5 (1): 119-124.

Karbassi A. R., Monavari S. M., Nabi Bidhendi G. R., Nouri J. and Nematpour K. (2008). Metal pollution assessment of sediment and water in the Shur River. Environ. Monitor. Assess. 147 (1-3): 107-116.

Lee C. L., Li X. D., Zhang G., Li J., Ding A. J. and Wang T. (2007). Heavy metals and $\mathrm{Pb}$ isotopic composition of aerosols in urban and suburban areas of Hong Kong and Guangzhou, South China Evidence of the longrange transport of air contaminants. Environ. Pollut. 41(2): 432-447.

Lohani M. B., Singh S., Rupainwar D. C. and Dhar D. N. (2008). Seasonal variations of heavy metal contamination in river Gomti of Lucknow city region. Environ. Monitor. Assess., 147 (1-3): 253-263.

Pandey J., Shubhashish K. and Pandey R. (2009). Metal contamination of Ganga River (India) as influenced by atmospheric deposition. Bull. Environ. Contam. Toxicol. 83 (2): 204-209.

Singh K. P., Mallik A., Mohan D., and Sinha S. (2004). Multivariate statistical techniques for the evalution of spatial and temporal variations in water quality of Gomti river (India): A case study. Water Res., 38 (18): 3980- 3992.

Sundaray S. K., Panda U. C., Nayak B. B. and Bhatta D. (2006). Multivariate statistical techniques for the evaluation of spatial and temporal variation in water quality of Mahanadi river-estuarine system (India). A case study. Environ. Geochem. Health, 28 (4): 317-330.

Suthar S. and Singh S. (2008). Vermicomposting of domestic waste by using two epigeic earthworms (Perionyx excavates and Perionyx sansibaricus). Int. J. Environ. Sci. Tech. 5 (1), 99-106.

USEPA U.S. Environmental Protection Agency, (1979). Methods for chemical analysis of water and wastes. 
Cincinnati: EPA-600/4-79-020.

Vinodhini R. and Narayanan M. (2008). Bioaccumulation of heavy metals in organs of fresh water fish Cyprinus carpio (Common carp). Int. J. Environ. Sci. Tech., 5(2): 179- 182.

Wilson A. L. (1974). The chemical analysis of water: general principles and techniques. The Chemical Society. Burlington House, London; 188 p.
Wong C. S. C., Li X. D., Zhang G., Qi S. H. and Peng X. Z., (2003). Atmospheric deposition of heavy metals in the Pearl River Delta, China. Atmos. Environ. 37 (6): $767-$ 776.

Wu Y. F., Liu C. Q. and Tu C. L., (2008). Atmospheric deposition of metals in TSP of guiyang, PR China. Bull. Environ. Contam. Toxicol., 80(5): 465-468.

Received :February 10, 2011;

Accepted : October 13, 2011 